\title{
THE DEVELOPMENT OF CONCEPTUAL BUILDING DESIGN TECHNOLOGY, USING QUALITY FUNCTION DEPLOYMENT AND AXIOMATIC DESIGN
}

\author{
Vilūnė LAPINSKIENE $\dot{1}^{1}$, Vytautas MARTINAITIS ${ }^{2}$ \\ Vilnius Gediminas Technical University, Vilnius, Lithuania

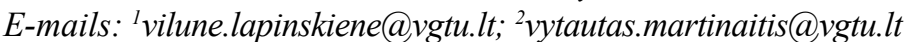

\begin{abstract}
Understanding issues early in the integrated design process is important, as this is when designers and engineers are able to have the largest impact on the final product. In this article the technology of conceptual architectural design for low energy buildings is proposed to address this issue. Here two methods - Quality function Deployment and Axiomatic design are used to develop the conception and to eliminate the main disadvantages of traditional building design. The integration of BIM, energy modelling (DesignBuilder) help to highlight the issue of energy efficiency at the early stage of building design, resulting in effective and more to posed requirements orientated design process.
\end{abstract}

Keywords: integrated building design, conceptual design, axiomatic design, quality function deployment.

\section{Introduction}

The contemporary architectural design process is growing in complexity due to various factors such as increasing size of projects, multiple agents involved in the design phases and technological dynamics. This complexity directly affects the design process and implies that the more advanced the development of a design, the greater the effort spent on an eventual change of parameters and solutions (Kiatake et al. 2017). The building design community is challenged by continuously increasing energy demands which are often in conjunction with ambitious goals for the indoor environment. In addition to stricter energy demands, the use of environmental assessment methods has increased considerably (Cole, Valdebenito 2013). As a result, the design team must try to optimize on a large number of criteria, such as energy demand, indoor environment, materials, life cycle cost, etc., which are often conflicting (Østergård et al. 2016).

On the building scale, the architectural design variables, which most influence the energy performance of a building, are related to the envelope design: the envelope materials, through their thermo- physical and optical properties, the envelope shape and the window area per cardinal direction as consequence of the building orientation (Oral, Yilmaz 2002, 2003). Most, if not all, of these variables are defined in the early design stages (Granadeiro et al. 2013). Although the project in the early design stage is very uncertain, all the decisions made have a great influence on the whole building's life cycle.

Traditionally in the Architectural / Engineering / Construction industry, the design and construction phases are conducted by multiple professional and trade disciplines having minimum interaction among them along a rather sequential process. These parties bring their different objectives to the project that are not necessarily aligned with the overall project objectives. Design professionals do not necessarily work together giving little or no consideration for the requirements or constraints of subsequent functions such as construction and operation and maintenance of the facility (Gomez 2016).

Furthermore, in the traditional building design process the following issues often occur: architectural-design solutions are often orientated only one-sidedly - to achieve good aesthetic view, some possible architectural variations, in order to fulfill customer's needs - are changed intuitively, based only on the experience of the architect. Therefore, the listed issues lead to the fact, that the technical systems and their capacity have to be selected according to the adopted architectural solutions, which increases systems capacity, investments and predispose inefficiency. Since architectural design is inseparable from the requirements of customers, such process does not ensure that the primary customer's requirements will be fulfilled successfully. 
The aim of this study is to present the technology of conceptual architectural design for low energy buildings. Here two design methods - Quality Function Deployment (QFD) and Axiomatic Design are integrated in the design process, whose help to eliminate the main disadvantages of conventional design process and draw together the Integrated Building Design (IBD) team from the first stages of the project. As the incorporation of QFD and Axiomatic design in the context of Integrated Building Design is uncommon, the application of them here is promising. Made-up recommendation systems and the use of design/modeling tools - Building Information Modeling (BIM) and Designbuilder improve the main weakness of Axiomatic Design - developing solution concepts. The proposed technology results in effective and more to posed requirements orientated building design.

\section{Design methods}

Quality function deployment and Axiomatic design are the methods/design approaches, which have been widely used in other engineering fields, but also have a big potential in Integrated Building Design process, as it was used only in few cases.

Quality Function Deployment (QFD) is a very well-known design method, developed in late 1960 in Japan, and used with the aim of translating Customer Needs (CNs) and wants into technical design requirements by means of the use of a series of matrices, called House of Quality (HoQ), with the objective to satisfy the customers' expectations improving the quality level of the product at the same time (Fargnoli 2006; Shahi, Alipour 2016). Series of matrices ensures that every customer need is addressed by at least one element in the design, and further helps designers better understand the most important design elements. In light of the QFD's ability to capture the Voice of Customer (VoC) and map it into requirements, and the AD's ability to guide the design process from high-level requirements into a conceptual design, combining the two processes seems a beneficial match (Gilbert et al. 2016).

Singgih et al. (2013) noticed such benefits of QFD the method reduces barriers associated with cross-functional product development, help to change corporate culture, has tangible benefits such as further reducing cycle time, reduce development costs, and increases productivity. An important benefit of QFD is its effectiveness in capturing, prioritizing and stabilizing customer needs.

Quality Function Deployment has been applied in quite different case studies. Shahi, Alipour (2016) integrated QFD, Axiomatic Design and Sustainable design for the satisfaction of an airplane tail stakeholders, Yamashina et al. (2017) described a new method, which systematically integrates QFD with TRIZ for effective and systematic creation of technical innovation for new products. Singgih et al. (2013) applied QFD four phases to consider not only the quality but also factor in the time and cost in developing a products. Singhaputtangkul et al. (2013) used QFD for decision-making problems when assessing building envelope materials and designs for a private high-rise residential building in the early design stage. Gilbert et al. (2014) study proposed a new systematic approach to the conceptual design of construction projects - specifically temporary housing - by combining Quality Function Deployment (QFD) and Axiomatic Design (AD), which helped to ensure that the design meets customer's needs, as well as satisfies the design objectives in a logical sequence.

Another mentioned method - Axiomatic Design (AD) - is a design methodology used to change the conventional decision making solely depending on the individual experience and intuition in the design process to a scientific approach aiming at creating optimum designs (Sawaguchi et al. 2015). The method is proposed to compose a scientific and systematic basis that provides structure to design process for engineers. The primarily goal of $\mathrm{AD}$ is to provide a thinking process to create a new design and/or to improve the existing design (Suh 2005; Kahraman 2010).

The Axiomatic Design Theory was developed around 1980 by Dr. Nam P. Suh of MIT (Massachusetts Institute of Technology) as The Principle of Design (Rolli et al. 2015) in the design process. Dr. Nam Suh developed this approach to try to find common elements between good designs and contrast them to bad designs. His investigation led to focusing on the relationship between needs and their satisfaction, encapsulated in two Axioms. The goal of any design is to reach the highest quality design solution satisfying needs while minimizing resources utilized (Benavides 2012; Hundal 1997). This result of an Axiomatic Design process is a structured description of how customer needs are systematically satisfied that fulfills all the needs of the customer, in the fewest iterations (Oli, Foley 2015; Foley, Harðardóttir 2016).

Some researches noticed the following benefits of $\mathrm{AD}$ : $\mathrm{AD}$ approach allows performing the control of process and solution quality (Marchesi et al. 2014), the flexibility it provides (Gilbert et al. 2013), help to conceive controllable and manageable designs (Borgianni, Matt 2016), beyond fulfilling initially posed requirements. Brown (2005) made the conclusions, that axiomatic design eliminate many of the difficulties with teaching traditional design. 
Axiomatic design was used on the concept of ideality and ideal solutions within design, with a particular focus on systems engineering and new product development. (Borgianni, Matt 2016; Zhu et al. 2016) applied AD in the design case of Rehabilitation Robot. Cavique, GonçalvesCoelho (2009) followed the Axiomatic Design (AD) to examine deeper the regulation requirement to reduce the energy consumption in HVAC systems. Kahraman, Cebi (2009) used AD as one of the methods for multiattribute selection among renewable energy alternatives. Creative $\mathrm{AD}$ was deployed in visual art project, where the results have shown that it made the engineer-artist collaboration and communication easier (Foley, Harðardóttir 2016).

The building design is a complicated process due to the fact, that different groups participate in the process, who have to collaborate and check their solutions in the early stage of the design. Furthermore, the customer here is essential, because his needs must be satisfied and the restrictions regarded. This brings about the interests of other IBD groups as their operating principles or regulations must also be met. That is why the involvement of QFD and AD in the Integrated Building Design process would be advantageous, while the benefits of each would change and improve the traditional building design process.

\section{Quality function deployment (QFD)}

The series of matrices, called House of Quality (HoQ) can have many forms, but all of them include 6 basic parts, presented in Fig. 1: customer requirements, technical requirements (design characteristics), a planning matrix, an interrelationship matrix, a technical correlation matrix, and a technical priorities/benchmarks and targets.

The initial stage starts in forming the matrix of customers requirements - it includes determining, clarifying, and specifying the customers' needs. This step is important, because it is the initial matrix from which the following matrices are formed. For this purpose the interviews, surveys and other communication methods can be used.

The second stage - forming a planning matrix. The main purpose of it is to compare how well the team met the customer requirements compared to its competitors. The matrix also shows the weighted importance of each requirement that the team and its competitors are attempting to fulfill (Tapke et al. 1997).

Technical (design characteristics) requirements - This is an engineering attribute matrix that is formed by a team of designers. It reflects the formation of the characteristics of the customers matrix ("What?") in the technical characteristics ("How?").

The purpose of interrelation matrix is to map the customer requirements into engineering characteristics that must be adjusted to fulfill the customer needs. The trend and the strength of those relation- ships are recorded in the relationship matrix with special symbols. The customer attributes are usually bundled according to an affinity criterion (Gonçalves-Coelho et al. 2005).

A technical correlation matrix - The triangular roof matrix is intended to identify whether the technical criteria (requirements) that describe a product improve or aggravate one another. When comparing each pair of criteria for this matrix, the IBD team raises the question: does the improvement of one criterion improve or worsen another? If the answer is that, however, the improvement of one criterion has led to a deterioration in another criterion, the designers need a compromise or a "-" sign in the matrix, otherwise the "+" should be written. The different levels of positive or negative interactions can also be depicted in different colors.

Technical priorities/benchmarks and targets - This is the final QFD matrix that summarizes all matrix data and team discussions. It usually consists of 3 parts: Technical priorities - the importance of each technical indicator

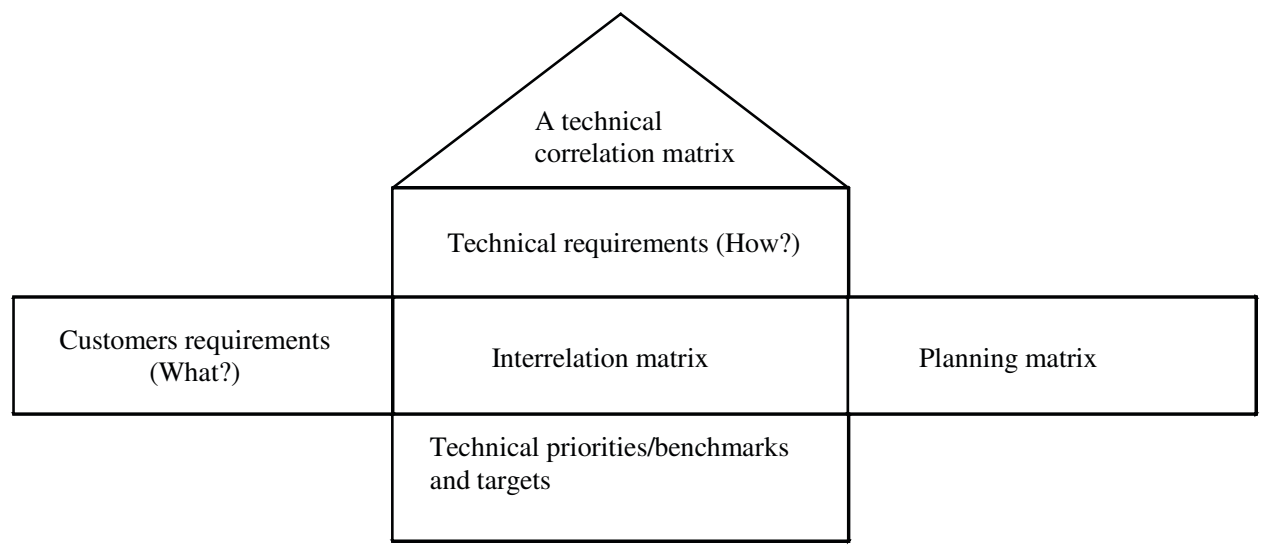

Fig. 1. The matrices of House of Quality (Tapke et al. 1997) 
(requirement) against the requirements specified by the customer. The interconnection is described by multiplying and then summing the values from the planning and relationship matrices. Later, they are summed up for each criterion separately. Competitive comparisons - technical requirements (criteria) that have been identified as important are compared to or with the parameters of the product in the production company or competitive. This shows the relative technical position of the product in the general context. The goals are the final step that defines the values of the product targets to be achieved. Creating this matrix allows these goals to be identified and ranked, with a good understanding of the requirements of the locker and the company's activities.

\section{Axiomatic design}

$\mathrm{AD}$ is a systems design methodology that uses matrix methods to systematically analyze the transformation of customer needs into functional requirements, design parameters, and process variables. $\mathrm{AD}$ uses design principles or design axioms governing the analysis and decision making process in developing high quality product or system designs (Gomez 2016).

The design objects in Axiomatic Design can be expressed in four different domains: the customer domain, the functional domain, the physical domain and the process domain. Fig. 2. shows the mapping process between these domains.

The customer domain is characterized by Customer Needs (CNs), that are expected from the product. In the functional domain, the customer needs are described as Functional Requirements (FR) and Constrains (C's). To satisfy the FR's, the design parameters (DP) must be clearly understood in the Physical domain. In order to get the final design parameters, with accordance to Design Parameters, a process is created, that is characterized by Process variables (PV's) in Process domain.

Product design can be mathematically expressed by the following design equation:

$$
\{F R\}=[A]\{D P\}
$$

where $[A]$ is the design matrix.
Different sets of DP can satisfy the functional requirements of Eq. (1) which means that one can choose between different design solutions. The Axiomatic design uses two Axioms to improve a design process - Independence axiom and Information axiom. The first - independence axiom, states that the independence of functional requirements (FRs) must always be maintained, where FRs are defined as the minimum set of independent requirements that characterizes the design goals (Suh 2005). Then, the other - information axiom, states that the design having the smallest information content is the best design among those designs that satisfy the independence axiom (Suh 1990). The information axiom is a conventional method and facilitates the selection of proper alternative that has minimum information content (Kahraman 2010).

Axiomatic design states, that there some level of abstraction, when a FR can be decomposed into independent child FRs belonging to the following level. All FR's are verbalized ranges of design solution, where the union of child functions should fulfill the parent. To help defining a solution there are some verbalized bounds, called constraints, which appear in the decomposition process by influencing the chosen DPs. Each FR will require the choice of a DP that performs it, which will influence the choice of all the subsequent children FRs. This is called the zigzagging process performed between the functional and the physical domains until one reaches the most detailed DP (Fig. 3) (Suh 1998; Cavique, Gonçalves-Coelho 2009).

\section{The technology of conceptual architectural design for low energy buildings}

In this work, the technology of conceptual architectural design for low energy buildings was formed on purpose to eliminate the gaps of traditional building design process, to collaborate the design team and to highlight the energy characteristics in the early stage of the building design. As Integrated Building design is inherent with Building Information Modeling (BIM) - all the technology

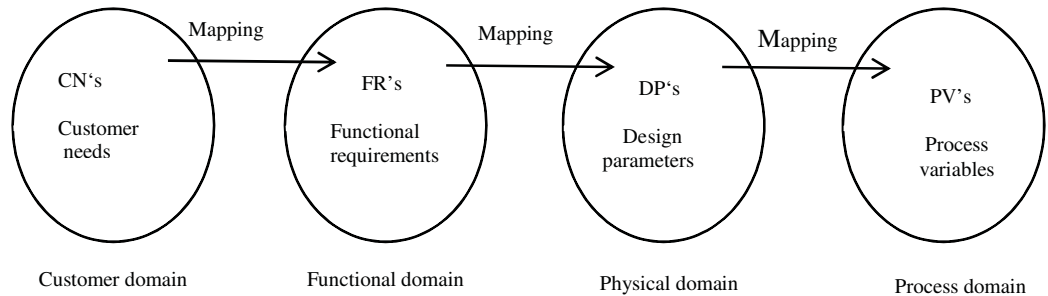

Fig. 2. Mapping process between the domains (Foley, Harðardóttir 2016)



Fig. 3. The zigzagging process performed between the functional and the physical domains (Suh 1998) 
procedures are presented in different Integrated Building Design and BIM stages, presented in Fig. 4. Here in order to establish an efficient Integrated BIM based Building design technology, we offer consistently implement QFD and $\mathrm{AD}$ procedures in the pre-design stage.

The goal of this technology is the concept architectural design - that in preliminary design stage. The pre-design stage contains three components - the analysis of initial data, consistent implementation of Quality function deployment (QFD) and Axiomatic design (AD). The preliminary design incorporates other design/modeling/analysis tools, which will be presented in the more detailed technology with information flows steps by step Fig. 5 .

\begin{tabular}{|c|c|c|c|c|c|c|}
\hline \multicolumn{4}{|c|}{ Planning / Designing IBD+BIM } & \multirow[b]{4}{*}{ 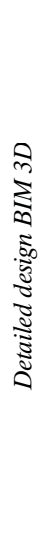 } & \multirow[b]{4}{*}{ 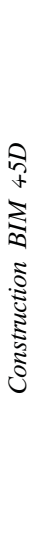 } & \multirow{4}{*}{  } \\
\hline \multicolumn{3}{|c|}{ PRE-DESIGN } & PRELIMINARY & & & \\
\hline Initial data & $\begin{array}{l}\text { Quality function } \\
\text { deployment QFD }\end{array}$ & Axiomatic design & $\begin{array}{c}\text { Design: Architecture and } \\
\text { Technology }\end{array}$ & & & \\
\hline $\begin{array}{l}\text { Site details } \\
\text { - Regulations } \\
\text { - Physical and } \\
\text { functional } \\
\text { limitations } \\
\text { - The purpose of the } \\
\text { building }\end{array}$ & $\begin{array}{l}\text { Determination/rating of } \\
\text { customers-IBD team } \\
\text { needs, their } \\
\text { compatibility: } \\
\text { - Identification and } \\
\text { ranking the needs of } \\
\text { the client and the IBD } \\
\text { team } \\
\text { - Transformation of } \\
\text { needs into technical } \\
\text { parameters }\end{array}$ & $\begin{array}{l}\text { Development of } \\
\text { conceptual building } \\
\text { design: } \\
\text { - Evaluation of } \\
\text { technical indicators } \\
\text { and design } \\
\text { parameters } \\
\text { - Axiom satisfaction } \\
\text { - Concept } \\
\text { Development and } \\
\text { Evaluation }\end{array}$ & $\begin{array}{l}\text { Determination of criteria } \\
\text { values } \\
\\
\text { - Schematic-volume } \\
\text { design } \\
\text { - Structural modeling } \\
\text { - Building energy } \\
\text { modeling } \\
\text { - Modeling of energy } \\
\text { systems } \\
\text { - Life cycle analysis }\end{array}$ & & & \\
\hline
\end{tabular}

Fig. 4. The technology of conceptual architectural design in different construction stages



Fig. 5. The technology of conceptual architectural design 
In this work, we propose a 6-step procedure for concept architectural design:

STEP1 - The Analysis of initial data. All the information, what is related to locality, available energy recourses, building type, its functional limitations, regulations - should be assessed by different groups, which participate in Integrated Building Design process, refer to their working competence.

STEP 2 - According to the initial information, the customer specifies his individual requirements and limitations for the design project. The suggested change is that the architect and the IBD team also provide their view and requirements for the design process. Following the QFD method, the customer should rate all the composed list of the requirements, and the engineers transform them into measurable technical requirement. In order to combine QFD and Axiomatic Design, the modified QFD, proposed by (Gilbert et al. 2016) is used - here technical requirements are extended into the functional, non-functional requirements and limitations. If engineers follow this procedure in accordance to their working field, the transformation becomes more efficient and goal-orientated.

STEP 3 - the aim of this steps is the development of the concept architectural design. The Axiomatic design here splits in to two parts. In the first one - all technical requirements - functional, non-functional and limitations are assessed and the design parameters are determined. All of them must satisfy the Independence Axiom and hereupon the concept idea should start formulating.

The made-up design recommendations here play the support role - they describe the influence of building elements on different design criteria and link measures to improve them. Considering the main project requirements, the design options and concept solutions are selected more accurately and efficiently.

STEP 4 - is the determination of criteria values for the building design alternatives. Here the instruments for the mostly analyzed requirements (criteria) are presented: Building modeling, energy modeling and LCA, where the use of them results in effective and more to posed requirements oriented design process. In this case, the chosen tools are more focused to highlight energy characteristics of the building.

STEP 5 - is the second part of Axiomatic design, there the suitable solutions has to satisfy the Information Axiom. In suitable option we pass to detailed design process (STEP $6 a$ ), if not suitable - follow next steps (6b1 and 6b2).

STEP 6b1-Component analysis of adopted solutions. According to the initial requirements, the analyzed solution should be analyzed by design components - with respect to initial requirements and design recommendations - new design solution composed - STEP 6b2. Component analysis here is important, because the assessment of the design parameters was done in ensuring every technical requirements.

Following the procedure, the design process becomes more initial requirements orientated and accurate, as here all the design team is involved. The presented criteria and instruments for the most commonly used requirements are presented, but can be easily adapted for different ones.

\section{Future work}

The future work would be to co-operate with an architect and propose two design processes - the common design process and the alternative - with proposed technology of conceptual architectural design. Here it would be possible to compare the design processes and the characteristics of the designed buildings.

\section{Conclusions}

The traditional building design process faces many challenges related to the design team, the efficiency of the design solutions and many conflicting requirements, which have to be fulfilled.

The modern design/modelling and analysis tools facilitate the building design process, but there is still the challenge to fulfil all the submitted requirements, wherefore human assistance is needed. Seeking to maximize the effectiveness of this process, the developed technology integrates two design approaches - The Quality function Deployment and Axiomatic Design, which are more in line with contemporary approach to the design process. While in the process of Integrated Building Design the role on customer needs is strengthen, here the process parameters are available for all the participants of the project, so the conditions are created for the early design stage corrections. As the results, the technology involve the methods, which are still rarely used in Integrated Building Design, but show significant potential.

\section{Disclosure statement}

Authors declare that have no competing financial, professional, or personal interests from other parties.

\section{References}

Benavides, E. M. 2012. Advanced engineering design - an integrated approach. Woodhead Publishing.

Borgianni, Y.; Matt, D. T. 2016. Ideality in Axiomatic Design and beyond, Procedia CIRP 53: 95-100. https://doi.org/10.1016/j.procir.2016.07.029 
Brown, C. A. 2005. Teaching Axiomatic Design to engineers theory, applications, and software, Journal of Manufacturing Systems 24(3): 186-195.

Cavique, M.; Gonçalves-Coelho, A. 2009. Axiomatic design and HVAC systems: an efficient design decision-making criterion, Energy and Buildings 41: 146-153. https://doi.org/10.1016/j.enbuild.2008.08.002

Cole, R. J.; Valdebenito, M. J. 2013. The importation of building environmental certification systems: international usages of BREEAM and LEED, Building Research \& Information 41(6): 662-676. https://doi.org/10.1080/09613218.2013.802115

Fargnoli, F. K. 2006. Sustainable design of modern industrial products, in the 13th CIRP International Conference of Life Cycle Engineering, 189-195, 2006, Leuven.

Foley, J. T.; Harðardóttir, S. 2016. Creative axiomatic design, Procedia CIRP 50: 240-245. https://doi.org/10.1016/j.procir.2016.04.116

Gilbert, L. R.; Omar, M. A.; Farid, A. 2016. Axiomatic design in large systems: an application of quality function deployment and axiomatic design to the conceptual design of temporary housing stakeholders. Springer, 216-240.

Gilbert, L. R.; Omar, M.; Farid, A. M. 2014. An integrated QFD and Axiomatic design methodology for the satisfaction of temporary housing stakeholder, in the 8th International Conference on Axiomatic Design, Proceedings of ICAD, 24-26 September 2014, Campus de Caparica.

Gilbert, L. R.; Omar, M.; Farid, A. M. 2013. An axiomatic design based approach to civil engineering, in the 2nd International Workshop on Design in Civil and Environmental Engineering, 28-29 June 2013, Worchester, MA, USA.

Gomez, L. 2016. The use of axiomatic design in the development of an integrated, Bim based design process: a dissertation. Worchester polytechnic institute.

Granadeiro, V., et al. 2013. Envelope-related energy demand: a design indicator of energy performance for residential buildings in early design stages, Energy and Buildings 61: 215-223 [online], [cited 20 June 2017]. Available from Internet: http://linkinghub.elsevier.com/retrieve/pii/ S0378778813000947

Gonçalves-Coelho, A. M.; Mourão, A. J. F.; Pereira, Z. L. 2005. Improving the use of QFD with Axiomatic Design, Concurrent Engineering 13(3): 233-239. https://doi.org/10.1177/1063293X05056787

Hundal, M. S. 1997. Systematic mechanical design: a cost and management per- spective. New York, NY: ASME Press.

Yamashina, H.; Ito, T.; Kawada, H. 2017. Innovative product development process by integrating QFD and TRIZ, International Journal of Production Research 40(5): 10311050. https://doi.org/10.1080/00207540110098490

Kahraman, C. 2010. Selection among renewable energy alternatives using fuzzy axiomatic design: the case of Turkey, Journal of Universal Computer Science 16(1): 82-102.

Kahraman, C.; Cebi, S. 2009. A comparative analysis for multiattribute selection among renewable energy alternatives using fuzzy axiomatic design and fuzzy analytic hierarchy process, Energy 34(10): 1603-1616. https://doi.org/10.1016/j.energy.2009.07.008
Kiatake, M., et al. 2017. A case study on the application of the theory of inventive problem solving in architecture, Architecrural Engineering and Design Management 8(2): 90-102. https://doi.org/10.1080/17452007.2012.659504

Marchesi, M., et al. 2014. Axiomatic design approach for the conceptual design of sustainable buildings, in the 8th International Conference on Axiomatic Design, Proceedings of ICAD, 24-26 September, 2014, Campus de Caparica.

Óli, S. G.; Foley, J. T. 2015. Low-cost spectrometer for Icelandic chemistry education, in Proceedings of 9th International Conference on Axiomatic Design (ICAD), Vol. 34. Procedia CIRP. Florence, Italy: Elsevier ScienceDirect, 2015.

Oral, G. K.; Yilmaz, Z. 2002. The limit U values for building envelope related to building form in temperate and cold climatic zones, Building and Environment 37: 1173-1180. https://doi.org/10.1016/S0360-1323(01)00102-0

Oral, G. K.; Yilmaz, Z. 2003. Building form for cold climatic zones related to building envelope from heating energy conservation point of view, Energy and Buildings 35: 383-388. https://doi.org/10.1016/S0378-7788(02)00111-1

Østergård, T.; Jensen, R. L.; Maagaard, S. E. 2016. Building simulations supporting decision making in early design - a review, Renewable and Sustainable Energy Reviews 61: 187-201. https://doi.org/10.1016/j.rser.2016.03.045

Rolli, F.; Giorgetti, A.; Citti, P. 2015. Integration of holistic non-conformities management and axiomatic design: a case study in Italian income tax re- turns management, in Proceedings of 9th International Conference on Axiomatic Design (ICAD, 2015), vol. 34. Procedia CIRP. Florence, Italy: Elsevier. https://doi.org/10.1016/j.procir.2015.07.076

Sawaguchi, M.; Shintaro, I. V.; Izumi, H. 2015. Effectiveness of conceptual design process respecting "The Axiomatic Design Theory", Procedia Engineering 131: 1050-1063. https://doi.org/10.1016/j.proeng.2015.12.423

Shahi, M.; Alipour, A. 2016. Integration axiomatic design with quality function deployment and sustainable design for the satisfaction of an airplane tail stakeholders, Procedia CIRP 53: 142-150. https://doi.org/10.1016/j.proeng.2015.12.423

Singhaputtangkul, N. Low, S. P. Teo, A. L. Hwang, B. G. 2013. Knowledge-based Decision Support System Quality Function Deployment (KBDSS-QFD) tool for assessment of building envelopes, Automation in Construction 35(2013): 314-328. Elsevier ScienceDirect.

Singgih, M. L.; Trenggonowati, D. L.; Karningsih, P. D. 2013. Four phases Quality Function Deplyment (QFD) by considering KANO concept, time and manufacturing cost, in the 2nd International Conference of Engineering and Technology Development, ICETD 2013, Indonesia.

Suh, N. P. 1995. Design and operation of large systems, Journal of Manufacturing Systems 14: 203-213. https://doi.org/10.1016/0278-6125(95)98887-C

Suh, N. P. 2005. Complexity theory and applications. New York: Oxford University Press.

Suh, N. P. 1998. Axiomatic design: advances and applications. Oxford University Press.

Suh, N. P. 1990. The principles of design. New York: Oxford University Press. 
Tapke, J., et al. 1997. House of quality. Steps in understanding the house of quality [online], [cited 15 June 2017]. Available from Internet: http://www.public.iastate.edu/ vardeman/ IE361/f01 mini/johnson.pdf.

Zhu, A.; He, S.; Liu, Y. 2016. Conceptual design of customised lower limb exoskeleten rehabiliation robot based on axiomatic design, Proceedia Engineering 53: 219-224.

\section{KONCEPCINIO PASTATO PROJEKTAVIMO TECHNOLOGIJA, TAIKANT KOKYBĖS FUNKCIJOS IŠSKLEIDIMO IR AKSIOMATINIO PROJEKTAVIMO METODUS}

\section{Lapinskienè, V. Martinaitis}

\section{Santrauka}

Identifikuoti problemas ankstyvajame integruoto projektavimo procese yra labai svarbu, nes tuomet projektuotojai ir dizaineriai gali turèti didžiausią itaką galutiniam sprendiniui. Šiame straipsnyje pristatoma sukurta koncepcinio architektūrinio projektavimo technologija, skirta mažaenergiams pastatams. Kuriant pastato koncepcijac, taikomi du metodai - kokybès funkcijos išskleidimo ir aksiomatinio projektavimo. Jie padeda išvengti pagrindinių tradicinio projektavimo trūkumų. BIM (Building Information Modelling) ir energinio modeliavimo priemoniu integravimas leidžia išryškinti energinio efektyvumo problematiką jau ankstyvajame projektavimo etape, o tai lemia veiksmingą ir labiau i pradinius reikalavimus orientuotą projektavimo procesą.

Reikšminiai žodžiai: integruotas pastatų projektavimas, koncepcinis projektavimas, aksiomatinis projektavimas, kokybès funkcijos išskleidimas. 